\title{
MEASLES IN POLAND IN 2016*
}

\author{
ODRA W POLSCE W 2016 ROKU*
}

National Institute of Public Health - National Institute of Hygiene in Warsaw

Department of Epidemiology of Infectious Diseases and Surveillance

Narodowy Instytut Zdrowia Publicznego - Państwowy Zakład Higieny

Zakład Epidemiologii Chorób Zakaźnych i Nadzoru

\begin{abstract}
INTRODUCTION. Since 1998 Poland has endorsed measles elimination programme which is coordinated by the World Health Organization (WHO). To accomplish measles elimination in the country, achievement of vaccination coverage at $95 \%$ in the population is needed, as is the monitoring of the epidemiological situation, i.e.: reporting on cases suspected of measles and conducting laboratory diagnostics in WHO Reference Laboratory. Polish Reference Laboratory is located at the Department of Virology (NIPH-NIH).

OBJECTIVES. The aim of the article is to analyze the epidemiological situation of measles in Poland in 2016 with presenting the measles vaccination coverage and the progress of the measles elimination programme in Poland.

MATERIAL AND METHODS. The epidemiological situation of measles in Poland was analyzed on the basis of the case-based questionnaires of cases suspected of measles sent to NIPH-NIH by the Sanitary and Epidemiological Stations, data from the publications: "Infectious diseases and poisonings in Poland in 2016" and "Vaccinations in Poland in 2016".

RESULTS. In 2016, 133 cases of measles were notified to the surveillance system in Poland (incidence 0,35 per 100000 population). The highest incidence was observed in the age group 0-4 and was estimated at 4.2 per 100000 population. Out of all cases, $93(69.9 \%)$ were hospitalized. No fatal cases due to the measles were reported. In 2016 the maintenance of high vaccination coverage among children aged 2 and 11 years old was observed - from $77.4 \%$ to $99.4 \%$ (primary vaccination, children born in $2009-2015$ ) and from $74.9 \%$ to $97.2 \%$ (booster vaccination, children born in 2003-2007).

CONCLUSIONS. The epidemiological situation of measles in 2016 in comparison with the situation in 2015, has deteriorated . Irrespective of that, the vaccination coverage was sustained at the satisfactory level. In order to achieve the improvement of the measles surveillance system, promoting of the measles elimination programme among the physicians is necessary with focusing on the necessity to report and laboratory confirm all measles cases and the cases suspected of measles.
\end{abstract}

Key words: measles, epidemiology, Poland 2016

\section{STRESZCZENIE}

WSTĘP. Odra od 1998 r. pozostaje objęta programem eliminacji koordynowanym przez Światową Organizację Zdrowia (WHO). Eliminacja odry w kraju możliwa jest pod warunkiem osiągnięcia 95\% poziomu zaszczepienia populacji, monitorowania sytuacji epidemiologicznej: rejestrowania wszystkich podejrzeń odry oraz prowadzenia diagnostyki laboratoryjnej w Laboratorium Referencyjnym WHO. Funkcję tę pełni Zakład Wirusologii (NIZP-PZH).

CEL PRACY. Celem pracy jest analiza wskaźników epidemiologicznych odry w Polsce w 2016 r. z uwzględnieniem stanu zaszczepienia populacji przeciw odrze oraz stopnia realizacji programu eliminacji odry Światowej Organizacji Zdrowia (WHO) w Polsce.

\footnotetext{
*Article was written under the task No.6/EM.1/2017 / Praca została wykonana w ramach zadania nr 6/EM.1/2017

(C) National Institute of Public Health - National Institute of Hygiene / Narodowy Instytut Zdrowia Publicznego - Państwowy Zakład Higieny
} 
MATERIAŁ I METODY. Analizę sytuacji epidemiologicznej odry w Polsce przeprowadzono na podstawie jednostkowych zgłoszeń podejrzeń zachorowań na odrę nadesłanych do NIZP - PZH przez Wojewódzkie Stacje Sanitarno - Epidemiologiczne, danych z biuletynu „Choroby zakaźne i zatrucia w Polsce w 2016 roku” oraz „Szczepienia ochronne w Polsce w 2016 roku”.

WYNIKI. W 2016 r. zarejestrowano w Polsce 133 zachorowania na odrę (zapadalność 0,12 na 100 000). U najmłodszych dzieci w wieku 0-4 lata, odnotowano najwyższą zapadalność wynoszącą 4,2 na 100 000. Hospitalizowano 93 chorych $(69,9 \%$ ), nie zgłoszono żadnego zgonu z powodu odry. W 2016 roku utrzymywał się wysoki stan zaszczepienia dzieci i młodzieży w wieku od 2 do 11 lat, od 77,4\% do 99,4\% (szczepienie podstawowe, roczniki 2009-2015) oraz od 74,9\% do 97,2\% (szczepienie przypominające, roczniki 2003-2008).

PODSUMOWANIE I WNIOSKI. Ocena wskaźników epidemiologicznych odry w 2016 roku w stosunku do roku 2015 uległa pogorszeniu. Pomimo, iż stan zaszczepienia populacji utrzymywał się na zadowalającym poziomie, w celu poprawy wskaźników jakości nadzoru nad odrą w Polsce celowe jest propagowanie programu eliminacji odry wśród lekarzy, podkreślając konieczność dokumentowania i laboratoryjnego potwierdzania wszystkich przypadków zachorowań i podejrzeń zachorowań na odrę.

Słowa kluczowe: odra, epidemiologia, Polska 2016 rok

\section{INTRODUCTION}

The measles is a disease that since 1988 has been the subject of integrated activities undertaken at the initiative of the World Health Organization (WHO) aimed at eliminating and then eradicating (1). The term "elimination" in relation to measles means a situation in which there is no endemic spreading of the disease, and in the case of virus reintroduction, the transmission of infections is not sustained. Achieving such a state requires:

- maintaining the level of inoculation of the population with two doses of vaccine at the level of $95 \%$ (obtaining community resistance),

- assessment of the percentage of vulnerable people in the population based on serological tests,

- permanent monitoring of the epidemiological situation, including recording all suspected measles and laboratory diagnostics for all measles suspected (2-3).

In Poland, as a part of the measles elimination program, all measles suspicions are reported and registered. Each of the suspicions should be confirmed / excluded by the determination of the level of specific antibodies in the IgM class or isolation of the virus from the biological material in the reference laboratory, accredited by the WHO (Laboratory of the Department of Virology NIZP - PZH). In order to detect antibodies in the IgM class, the material should be collected after 7 days from the onset of the rash (up to 45 days after the onset of the disease). However, in order to isolate the virus or carry out a molecular examination (PCR), the material should be collected within 1-4 days of the appearance of the rash. Molecular examination is used to identify the source and route of infection (4-5).

Before the introduction of vaccination for measles, they were commonplace. Epidemics occurred every

\section{WSTĘP}

Odra jest chorobą, która od roku 1988 jest przedmiotem zintegrowanych działań podejmowanych z inicjatywy Światowej Organizacji Zdrowia (WHO) ukierunkowanych na eliminację, a następnie eradykację (1). Termin „eliminacja” w odniesieniu do odry oznacza sytuację, w której nie występuje endemiczne szerzenie się zachorowań, zaś w przypadku reintrodukcji wirusa (zawleczenie), transmisja zakażeń nie jest podtrzymana. Osiągnięcie takiego stanu wymaga:

- utrzymania poziomu zaszczepienia populacji dwiema dawkami szczepionki na poziomie $95 \%$ (uzyskanie odporności zbiorowiskowej),

- oceny odsetka osób wrażliwych w populacji na postawie badań serologicznych,

- stałego monitorowania sytuacji epidemiologicznej, w tym rejestrowania wszystkich podejrzeń w kierunku odry i diagnostyki laboratoryjnej prowadzonej wobec wszystkich podejrzeń odry (2-3).

W Polsce w ramach programu eliminacji odry zgłaszaniu i rejestrowaniu podlegają wszystkie podejrzenia odry. Każde z podejrzeń powinno zostać potwierdzone/ wykluczone przez oznaczenie poziomu swoistych przeciwciał w klasie IgM lub izolację wirusa z materiału biologicznego w laboratorium referencyjnym, akredytowanym przez WHO (laboratorium Zakładu Wirusologii NIZP - PZH). W celu wykrycia przeciwciał w klasie IgM materiał do badania należy pobrać po upływie 7 dni od pojawienia się wysypki (do 45 dni po zachorowaniu). Natomiast w celu izolacji wirusa lub wykonania badania molekularnego (PCR), materiał należy pobrać w okresie 1-4 dni od pojawienia się wysypki. Badanie molekularne jest stosowane do identyfikacji źródła i drogi transmisji zakażenia (4-5).

Przed wprowadzeniem szczepień zachorowania na odrę były powszechne. Epidemie występowały co 2-3 lata. W Polsce przed wprowadzeniem szczepień 
2-3 years. In Poland, before the introduction of measles vaccinations (sixties), the number of registered cases ranged from 70000 to 130000 in years between epidemics and from 135000 to 200000 in epidemic years (6).

The measles vaccine comes in a combined (conjugated) form as a measles, mumps and rubella vaccine (so-called MMR). It includes live, weakened viruses. It does not contain adjuvants. Vaccination against measles belongs to the compulsory vaccination, entered into the annual calendar of vaccinations, administered in Poland in 13-14 months of age and 10 years of age. The vaccination effectiveness after 2 doses of vaccine is $98-99 \%(7)$.

\section{OBJECTIVES}

The aim of the work is to assess the epidemiological situation of measles in Poland in 2016 and its comparison to previous years, including the status of vaccination against measles.

In addition, the work aims to present the degree of implementation of the WHO measles eradication program, taking as a benchmark the sensitivity indicators of surveillance developed by the World Health Organization and assumptions (mentioned in the introduction) that are crucial for achieving the elimination of disease.

\section{MATERIAL AND METHODS}

The analysis of the epidemiological situation of measles in Poland in 2016 was carried out based on individual case reports/suspicionson measles sent to NIZP-PZH by Voivodship Sanitary and Epidemiological Stations and data from the annual bulletin "Infectious diseases and poisoning in Poland" in 2016 " (8).

The analysis of the state of population immunization in 2016 was based on data from the annual bulletin "Protective vaccinations in Poland in 2016" (9). According to the definition of the case of measles: clinical criteria are met by every person with fever and maculopapular rash, and at least one of the following three criteria: cough, rhinitis, conjunctivitis. The laboratory criteria are based on the fulfillment of at least one of the following four criteria:

- isolation of measles virus from clinical material,

- detection of measles virus nucleic acid in a clinical specimen,

- the presence of specific antibodies against the measles virus in the blood or saliva, characteristic of acute infection (IgM),

- detection of the measles virus antigen in the clinical specimen by direct immunofluorescence przeciw odrze (latach sześćdziesiątych) liczba rejestrowanych przypadków kształtowała się od 70000 do $130000 \mathrm{w}$ latach pomiędzy epidemiami oraz od 135000 do $200000 \mathrm{w}$ latach epidemicznych (6). Szczepionka przeciw odrze występuje w postaci połączonej (skoniugowanej) jako szczepionka przeciw odrze, śwince i różyczce (tzw. MMR). W jej skład wchodzą żywe, osłabione wirusy. Nie zawiera adiuwantów. Szczepienie przeciw odrze należy do szczepień obowiązkowych, wpisanych w coroczny Kalendarz Szczepień, podawanych w Polsce w 13-14 mies. życia oraz 10 roku życia. Skuteczność szczepienia po podaniu 2 dawek szczepionki wynosi 98-99\% (7).

\section{CEL PRACY}

Celem pracy jest analiza wskaźników epidemiologicznych odry w Polsce w 2016 roku oraz stanu zaszczepienia przeciw odrze $\mathrm{w}$ populacji polskiej. Ponadto praca ma na celu przedstawienie stopnia realizacji programu eliminacji odry WHO przyjmując za punkt odniesienia wskaźniki czułości nadzoru opracowane przez Światową Organizację Zdrowia oraz założenia (wymienione we wstępie) kluczowe dla osiągnięcia eliminacji choroby.

\section{MATERIAŁ I METODY}

Analizę sytuacji epidemiologicznej odry w Polsce w 2016 r. przeprowadzono na podstawie indywidualnych formularzy zgłoszeń przypadków/podejrzeń zachorowań na odrę nadesłanych do NIZP -PZH przez Wojewódzkie Stacje Sanitarno- Epidemiologiczne oraz danych pochodzących z rocznego biuletynu "Choroby zakaźne i zatrucia w Polsce w 2016 roku” (8).

Analizę stanu uodpornienia populacji w roku 2016 przeprowadzono w oparciu o dane pochodzące $\mathrm{z}$ rocznego biuletynu ,Szczepienia ochronne w Polsce w 2016 roku" (9). Zgodnie z brzmieniem definicji przypadku odry: kryteria kliniczne spełnia każda osoba, u której występuje gorączka oraz wysypka plamisto-grudkowa, oraz co najmniej jedno z następujących trzech kryteriów: kaszel, nieżyt śluzowy nosa, zapalenie spojówek. Kryteria laboratoryjne opierają się na spełnieniu co najmniej jednego z następujących czterech kryteriów:

- izolacji wirusa odry z materiału klinicznego,

- wykrycia kwasu nukleinowego wirusa odry w materiale klinicznym,

- wykazania obecności swoistych przeciwciał przeciw wirusowi odry w surowicy krwi lub ślinie, charakterystycznych dla ostrej infekcji (IgM),

- wykrycia $\mathrm{w}$ materiale klinicznym antygenu wirusa odry metodą immunofluorescencji bezpośredniej (DFA) z użyciem swoistych przeciwciał monoklonalnych odry. $\mathrm{W}$ interpretacji 
(DFA) using specific monoclonal antibodies. The interpretation of laboratory tests results should take into account previous measles vaccination. If a person has recently been vaccinated, it must be examined if there is a wild-type infection.

Epidemiological criteria are met at the time of establishing an epidemiological link involving the transmission of infection from person to person.

Applied case classification:

A. A possible case - every person who meets clinical criteria.

B. Probable case - each person meeting clinical and epidemiological criteria.

C. Confirmed case - every person who has recently been vaccinated against measles and meets clinical and laboratory criteria. In case of recent vaccination: any person who has been detected in a wild-type measles virus (10).

\section{RESULTS}

\section{Epidemiological situation of measles in 2016.}

The epidemiological situation of measles in 2016 as compared to the previous year was characterized by a significant increase in the number of cases (3-fold increase). In 2016, a total number of reported cases and suspected cases of measles was 133 (incidence 0.35 per 100,000) were registered in Poland. Measles cases were registered in 4 voivodeships (Tab. I). The highest number of cases occurred in Lubelskie voivodeships (73 cases in each, incidence respectively 3.42 per 100,000) and Mazowieckie voivodeships (30 cases in each, incidence respectively 0.56 per 100,000$)$. In 2016, 9 measles outbreaks were reported in four voivodeships (the biggest one in Lubelskie - 54 people, which is $40.6 \%$ registered cases in 2016). In total, 120 cases were registered in outbreaks.

The highest incidence rate was observed among children under 5 years of age $(4.2$ per 100,000$)$ and among children aged 5-9 years (1.4 per 100,000). Based on data from individual reports of cases, of 133 measles cases registered in 2016, 91 patients $(68 \%)$ were unvaccinated, 4 patients $(3 \%)$ vaccinated in accordance with the current vaccination calendar. For 13 cases $(9.8 \%)$ vaccination status was unknown.

In 2016, 93 cases of all registered ones (69.9\%) were hospitalized. Complications occurred in 12 patients $(9 \%)$, including 7 measles cases diagnosed with pneumonia. No deaths from measles were reported. wyników testów laboratoryjnych należy wziąć pod uwagę przebyte szczepienie przeciw odrze. Jeżeli dana osoba została zaszczepiona niedawno, należy zbadać, czy doszło do zakażenia dzikim wirusem.

Kryteria epidemiologiczne spełnione są w momencie stwierdzenia powiązania epidemiologicznego polegające na przeniesieniu zakażenia z człowieka na człowieka.

Stosowana klasyfikacja przypadków :

A. Przypadek możliwy- każda osoba spełniająca kryteria kliniczne.

B. Przypadek prawdopodobny - każda osoba spełniająca kryteria kliniczne i epidemiologiczne.

C. Przypadek potwierdzony - każda osoba, która w ostatnim czasie nie była szczepiona przeciw odrze oraz spełnia kryteria kliniczne i laboratoryjne. W razie niedawnego szczepienia: każda osoba, u której wykryto dziki szczep wirusa odry (10).

\section{WYNIKI}

\section{Sytuacja epidemiologiczna odry w roku 2016.}

Sytuacja epidemiologiczna odry w 2016 r. w porównaniu do roku poprzedniego, charakteryzowała się znacznym wzrostem liczby zachorowań (3-krotny wzrost). W Polsce w 2016 r. odnotowano 133 przypadki zachorowań na odrę, zapadalność 0,35 na 100000 ludności (w 2015 r. zarejestrowano 48 przypadków, zapadalność 0,12 na 100000 ludności).

Zachorowania na odrę odnotowano w 9 województwach (Tab.1). Najwięcej zachorowań wystąpiło w województwie lubelskim (73 zachorowania, zapadalność 3,42 na 100 000) oraz mazowieckim (30 zachorowań, zapadalność 0,56). W 2016 r. wystąpiło 9 ognisk, na terenie 4 województw (lubelskiego, podlaskiego, mazowieckiego, kujawsko-pomorskiego). Największe ognisko było w województwie lubelskim - 54 osoby (40,6\% wszystkich zgłoszonych przypadków). W ogniskach odnotowano 120 zachorowań.

Najwyższą zapadalność odnotowano wśród dzieci z grupy wieku 0-4 lata (4,2 na 100 000) oraz wśród dzieci 5-9 lat (1,4 na 100 000). Analiza danych pochodzących z indywidualnych zgłoszeń wskazywała, ze wśród 133 chorych 91 (68\%) stanowiły osoby nieszczepione, 4 (3,0\%) osoby zaszczepione zgodnie z obowiązującym kalendarzem szczepień oraz $13(9,8 \%)$ o nieznanym statusie zaszczepienia. Hospitalizowanych było 93 (69,9\%). Odnotowano 12 (9\%) różnych powikłań w przebiegu choroby, w tym $7 \mathrm{w}$ postaci zapalenia płuc. W 2016 roku nie odnotowano zgonu z powodu odry. 
Table I. Measles in Poland during 2008-2016. Number of suspected and confirmed cases and incidence per 100000 population by voivodeship

Tabela I. Odra w Polsce w latach 2008-2016. Liczba podejrzeń, potwierdzonych zachorowań i zapadalność na 100000 ludności wg województw

\begin{tabular}{|c|c|c|c|c|c|c|c|c|c|c|c|c|c|}
\hline \multirow{3}{*}{\multicolumn{2}{|c|}{ Voivodeship }} & \multicolumn{4}{|c|}{ Median 2008 - 2012} & \multicolumn{4}{|c|}{2015} & \multicolumn{4}{|c|}{2016} \\
\hline & & \multicolumn{2}{|c|}{ suspected cases } & \multicolumn{2}{|c|}{ mesasles cases } & \multicolumn{2}{|c|}{ suspected cases } & \multicolumn{2}{|c|}{ mesasles cases } & \multicolumn{2}{|c|}{ suspected cases } & \multicolumn{2}{|c|}{ mesasles cases } \\
\hline & & number & $\begin{array}{c}\text { inci- } \\
\text { dence } \\
\text { per } 100 \\
000\end{array}$ & number & $\begin{array}{l}\text { inci- } \\
\text { dence } \\
\text { per } 100 \\
000\end{array}$ & number & $\begin{array}{c}\text { inci- } \\
\text { dence } \\
\text { per } 100 \\
000\end{array}$ & number & $\begin{array}{c}\text { inci- } \\
\text { dence } \\
\text { per } 100 \\
000\end{array}$ & number & $\begin{array}{l}\text { inci- } \\
\text { dence } \\
\text { per } 100 \\
000\end{array}$ & number & $\begin{array}{l}\text { inci- } \\
\text { dence } \\
\text { per } 100 \\
000\end{array}$ \\
\hline & POLSKA & 127 & 0.33 & 70 & 0.18 & 133 & 0.35 & 48 & 0.12 & 148 & 0.37 & 133 & 0.35 \\
\hline 1. & Dolnośląskie & 13 & 0.45 & 14 & 0.49 & 9 & 0.31 & 4 & 0.14 & 2 & 0.06 & 1 & 0.03 \\
\hline 2. & Kujawsko-pomorskie & 6 & 0.29 & 2 & 0.10 & 4 & 0.19 & 1 & 0.05 & 4 & 0.19 & 1 & 0.05 \\
\hline 3. & Lubelskie & 7 & 0.32 & 7 & 0.32 & 0 & 0.00 & 0 & 0 & 73 & 3.42 & 73 & 3.42 \\
\hline 4. & Lubuskie & 1 & 0.10 & 1 & 0.10 & 1 & 0.1 & 0 & 0 & 1 & 0.10 & 0 & 0.00 \\
\hline 5. & Łódzkie & 5 & 0.20 & 2.5 & 0.10 & 2 & 0.08 & 0 & 0 & 0 & 0.00 & 0 & 0.00 \\
\hline 6. & Małopolskie & 7 & 0.21 & 3 & 0.09 & 18 & 0.53 & 11 & 0.33 & 3 & 0.06 & 2 & 0.06 \\
\hline 7. & Mazowieckie & 22 & 0.42 & 10 & 0.19 & 27 & 0.50 & 8 & 0.15 & 35 & 0.60 & 30 & 0.56 \\
\hline 8. & Opolskie & 2 & 0.20 & 3 & 0.29 & 3 & 0.30 & 1 & 0.1 & 0 & 0.00 & 0 & 0 \\
\hline 9. & Podkarpackie & 4 & 0.19 & 3 & 0.40 & 3 & 0.14 & 1 & 0.05 & 3 & 0.14 & 0 & 0 \\
\hline 10. & Podlaskie & 1 & 0.08 & 0 & 0.00 & 2 & 0.17 & 1 & 0.08 & 22 & 1.85 & 22 & 1.85 \\
\hline 11. & Pomorskie & 1 & 0.04 & 1 & 0.04 & 4 & 0.17 & 1 & 0.04 & 0 & 0.00 & 0 & 0.00 \\
\hline 12. & Śląskie & 10 & 0.22 & 5 & 0.11 & 21 & 0.46 & 2 & 0.04 & 2 & 0.04 & 1 & 0.02 \\
\hline 13. & Świętokrzyskie & 1 & 0.08 & 1 & 0.08 & 0 & 0 & 0 & 0 & 0 & 0 & 0 & 0 \\
\hline 14. & Warmińsko-mazurskie & 1 & 0.07 & 1 & 0.07 & 2 & 0.14 & 0 & 0 & 0 & 0.00 & 0 & 0 \\
\hline 15. & Wielkopolskie & 11 & 0.32 & 9 & 0.27 & 16 & 0.46 & 7 & 0.2 & 2 & 0.06 & 2 & 0.06 \\
\hline 16. & Zachodniopomorskie & 2 & 0.09 & 1 & 0.06 & 21 & 1.23 & 11 & 0.64 & 1 & 0.06 & 1 & 0.06 \\
\hline
\end{tabular}

\section{Vaccinations against measles in 2016.}

The existing scheme of vaccination against measles remained unchanged since 2005 and consists of primary dose for children at 13-14 months and booster dose at 10 years of age. Live attenuated combined vaccine against measles, mumps and rubella (MMR) is used. In 2016, Poland maintained a high vaccination coverage of children. As of 31st December 2016, vaccination coverage of children and youth aged 2-11 years ranged from $77.4 \%$ do $99.4 \%$ (primary vaccination in children born in 2009-2015) and from 74.9\% do 97.2\% (booster dose in children born in 2003-2007) (Tab. II). As in previous years, differences between voivodeships in performance of primary vaccination in children at 13-15 months of age were observed. Percentage of children born in 2015 and 2016 vaccinated with trivalent vaccine against measles, mumps and rubella (77.4\% in Poland).

\section{Measles Elimination Program implementation sta- tus in 2016.}

WHO European Region measles elimination strategy requires maintaining a sensitive and timely surveillance of measles and measles compatible cases, with serologic testing of at least one suspect case per
Wykonawstwo szczepień przeciw odrze w 2016 roku.

Od 2005 r. roku schemat szczepień przeciw odrze w Polsce pozostaje niezmieniony, obejmuje podanie pierwszej (podstawowej) dawki w 13-14 miesiącu życia oraz dawki przypominającej w 10 roku życia. Stosuje się żywą, atenuowaną, skojarzoną szczepionkę przeciw odrze, śwince i różyczce (MMR) podawaną podskórnie. W 2016 roku utrzymano wysoki stan zaszczepienia dzieci. W dniu 31 grudnia 2016 r. stan zaszczepienia dzieci i młodzieży w wieku od 2 do 11 lat był w granicach od $77,4 \%$ do $99,4 \%$ (szczepienie podstawowe, roczniki 2009-2015) oraz od 74,9\% do 97,2\% (szczepienie przypominające, roczniki 2003-2007) (Tab. II). Od kilku lat utrzymują się międzywojewódzkie różnice w wykonawstwie szczepień podstawowych u dzieci w 13-15 miesiącu życia. W 2016 r. odsetek dzieci z roczników 2015 oraz 2016, objętych szczepieniem podstawowym szczepionką MMR wynosił 77,4\% w skali kraju.

\section{Realizacja Programu Eliminacji Odry w Polsce w 2016 roku.}

Zgodnie ze strategią eliminacji odry opracowaną przez Europejskie Biuro Regionalne WHO, wymagane jest wykonywanie diagnostyki serologicznej w kierunku odry dla minimum 1 przypadku na 100000 mieszkań- 
100,000 population. Over time, a decrease in number of confirmed measles cases should be accompanied by an increase in the number of notified and laboratory tested suspected cases of measles. In Poland in 2016, the number of reported suspected measles cases was higher than in 2015, with a total of 148 cases and suspected cases of measles were reported in Poland which constitutes $56 \%$ of the expected reports and shows a low sensitivity of surveillance system (Fig. 1). ców. W miarę upływu czasu spadkowi liczby potwierdzonych zachorowań towarzyszyć powinien wzrost liczby zgłaszanych i weryfikowanych laboratoryjnie podejrzeń. W Polsce w roku 2016 liczba podejrzeń w kierunku odry była wyższa niż w roku 2015, w całym kraju zgłoszono ogółem 148 zachorowań i podejrzeń zachorowań na odrę. Stanowi to tylko $56 \%$ oczekiwanych zgłoszeń i świadczy o niedostatecznej czułości systemu nadzoru (Ryc. 1).

Table II. Number and percentage of children vaccinated against measles in Poland 2016 according to birth year (primary and booster vaccinations)*

Tabela II. Liczba i odsetek dzieci zaszczepionych przeciw odrze w Polsce w 2016 wg roku urodzenia (pierwsza i druga dawka)

\begin{tabular}{|c|c|c|c|c|c|c|c|c|c|c|}
\hline \multirow[b]{2}{*}{$\begin{array}{l}\text { Year of } \\
\text { birth }\end{array}$} & \multicolumn{2}{|c|}{$\begin{array}{c}\text { As of 31th December } \\
2012\end{array}$} & \multicolumn{2}{|c|}{$\begin{array}{c}\text { As of 31th December } \\
2013\end{array}$} & \multicolumn{2}{|c|}{$\begin{array}{c}\text { As of 31th December } \\
2014\end{array}$} & \multicolumn{2}{|c|}{$\begin{array}{c}\text { As of 31th December } \\
2015\end{array}$} & \multicolumn{2}{|c|}{$\begin{array}{c}\text { As of 31th December } \\
2016\end{array}$} \\
\hline & number & $\begin{array}{c}\% \\
\text { of children } \\
\text { vaccinated }\end{array}$ & number & $\begin{array}{c}\% \\
\text { of children } \\
\text { vaccinated }\end{array}$ & number & $\begin{array}{c}\% \\
\text { of children } \\
\text { vaccinated }\end{array}$ & number & $\begin{array}{c}\% \\
\text { of children } \\
\text { vaccinated }\end{array}$ & number & $\begin{array}{c}\% \\
\text { of children } \\
\text { vaccinated }\end{array}$ \\
\hline \multicolumn{11}{|c|}{ Primary dose } \\
\hline 2009 & 404820 & 98.9 & 405744 & 99.1 & 404026 & 99.4 & 404310 & 99.4 & 404410 & 99.4 \\
\hline 2010 & 395336 & 97.9 & 398282 & 98.7 & 399431 & 99.1 & 398001 & 99.1 & 397686 & 99.2 \\
\hline 2011 & 318126 & 83.6 & 370876 & 97.5 & 374312 & 98.7 & 375672 & 98.8 & 374750 & 99 \\
\hline 2012 & $\mathrm{x}$ & $\mathrm{x}$ & 314402 & 82.8 & 368575 & 97.5 & 373059 & 98.2 & 374596 & 98.5 \\
\hline 2013 & $\mathrm{x}$ & $\mathrm{x}$ & $\mathrm{x}$ & $\mathrm{x}$ & 287371 & 82.8 & 347449 & 96.3 & 351974 & 97.5 \\
\hline 2014 & $\mathrm{x}$ & $\mathrm{x}$ & $\mathrm{x}$ & $\mathrm{x}$ & $\mathrm{x}$ & $\mathrm{x}$ & 285343 & 77.9 & 350451 & 95.5 \\
\hline 2015 & $\mathrm{x}$ & $\mathrm{x}$ & $\mathrm{x}$ & $\mathrm{x}$ & $\mathrm{x}$ & $\mathrm{x}$ & $\mathrm{x}$ & $\mathrm{x}$ & 283040 & 74.9 \\
\hline \multicolumn{11}{|c|}{ Booster dose } \\
\hline 2003 & 255409 & 98.4 & 260467 & 77.3 & 274886 & 81.8 & 297083 & 88.9 & 320030 & 97.2 \\
\hline 2004 & 333594 & 98.6 & 309837 & 93.2 & 316426 & 95.3 & 319125 & 96.2 & 327583 & 97.3 \\
\hline 2005 & 344882 & 98.4 & 343371 & 98.6 & 270535 & 77.7 & 327171 & 94.1 & 334162 & 96.3 \\
\hline 2006 & $\mathrm{x}$ & $\mathrm{x}$ & $\mathrm{x}$ & $\mathrm{x}$ & $\mathrm{x}$ & $\mathrm{x}$ & 257839 & 71.5 & 336060 & 93.4 \\
\hline 2007 & $\mathrm{x}$ & $\mathrm{x}$ & $\mathrm{x}$ & $\mathrm{x}$ & $\mathrm{x}$ & $\mathrm{x}$ & $\mathrm{x}$ & $\mathrm{x}$ & 282160 & 74.9 \\
\hline 2008 & $\mathrm{x}$ & $\mathrm{x}$ & $\mathrm{x}$ & $\mathrm{x}$ & $\mathrm{x}$ & $\mathrm{x}$ & $\mathrm{x}$ & $\mathrm{x}$ & $\mathrm{x}$ & $\mathrm{x}$ \\
\hline
\end{tabular}

Along with a reliable evidence of the elimination of indigenous measles, efficient detection of the disease imported from other countries is also important in measles elimination strategy. Therefore, the key activities should be investigating all suspected cases of measles, including secondary cases in outbreaks, and performing genotyping of measles virus. In 2016, similarly to previous years, surveillance of measles suspected cases in the country was uneven. There was not registered sufficient number of suspected measles cases to meet or exceed the minimal threshold of measles elimination specified by the WHO as one case per 100 000 inhabitants was only achieved in voivodeship: lubelskim (73 reports,incidence 3.42/100,000), podlaskim (22 reports, incidence 1.85/100,000) (Tab.1).

Number of serological tests performed in suspected measles cases in 2016 was higher than in the previous year. Of 148 recorded cases and suspected cases of measles, 109 (73.6\%) were diagnosed with IgM ELISA test and were performed in the WHO reference laboratory in the Department of Virology NIPH - NIH.
W fazie eliminacji odry konieczne jest ścisłe monitorowanie podejrzeń zachorowania na odrę oraz przypadków wtórnych w ogniskach, jak również kontynuowanie genetycznych badań szczepów wirusa odry. Działania te umożliwią wiarygodne udokumentowanie eliminacji rodzimych zachorowań na odrę spodziewanej w najbliższych latach, jak również sprawne wykrywanie zachorowań zawlekanych z innych krajów. Tak, jak w latach ubiegłych, w 2016 roku nadzór nad podejrzeniami odry w skali kraju był nierównomierny. W 2016 r. tylko w województwach: lubelskim (73 zgłoszenia, 3,42/100 000 osób) oraz podlaskim (22 zgłoszenia, 1,85/100 000 osób) zgłoszono oczekiwaną liczbę przypadków podejrzanych (według WHO powinno być zgłoszone rocznie 1 podejrzenie na 100000 mieszkańców w danym województwie)(Tab. I).

Liczba wykonanych badań serologicznych w przypadkach podejrzenia zachorowania na odrę w roku 2016 była wyższa niż w 2015 roku. Na ogólną liczbę 148 zachorowań i podejrzeń zachorowania badanie serologiczne w klasie IgM wykonano w 109 przypadkach (73,6\%). Wszystkie badania wykonano w laboratorium referencyjnym w Zakładzie Wirusologii NIZP-PZH. 


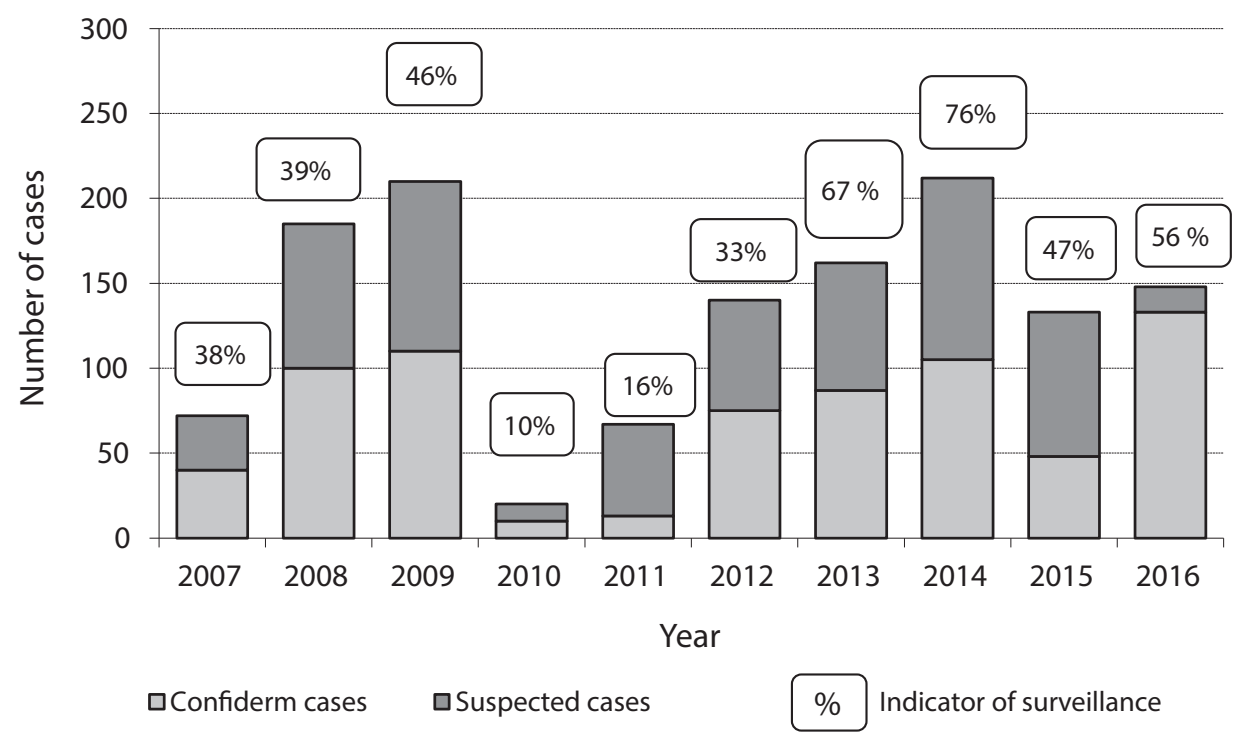

Fig 1. Measles surveillance performance in Poland 2007-2016.

Ryc. 1. Sprawność nadzoru epidemiologicznego nad odrą w Polsce w latach 2007-2016.

According to the law on control of infections and infectious diseases in humans (Act of 5 December 2008 on prevention and control of infections and infectious diseases in humans, Dz.U.08.234.1570 with further amendments) measles is subjected to statutory notification by a doctor within 24 hours from the time of diagnosis or suspicion of infection. The median number of days between the first visit to the doctor and notification of case or suspected measles cases to the local sanitary-epidemiological stations was 3 days and therefore exceeded the applicable time. To maintain high sensitivity of the serological diagnosis of measles, the specimen should be collected between 7 and 45 day after rash onset date. The highest titer in 2016 is observed on 9 days.

\section{CONCLUSIONS}

Despite the increase in the incidence of measles in 2016, compared to 2015, the number of registered suspicions of measles continues to be too low to the expected number.

In order to improve the quality of measles surveillance in Poland, it is advisable to promote a program for the elimination of measles among doctors and information on the plan and the degree of program implementation as well as on the current epidemiological situation of the disease in Poland.

The necessity to document and laboratory confirmation of all cases and suspected measles cases, including information about the role of the reference laboratory in the implementation of the program and the possibility of performing free serological tests, should also be underlined.
Zgodnie z ustawą o zwalczaniu zakażeń i chorób zakaźnych u ludzi (Ustawa z dnia 5 grudnia 2008 r. o zapobieganiu oraz zwalczaniu zakażeń i chorób zakaźnych u ludzi, Dz.U.08.234.1570 ze zm.) odra podlega ustawowemu obowiązkowi zgłoszenia w ciągu 24 godzin od momentu rozpoznania lub podejrzenia zakażenia przez lekarza. Mediana liczby dni pomiędzy pierwszą wizytą u lekarza a zgłoszeniem przypadku podejrzenia zachorowania do lokalnej stacji sanitarno-epidemiologicznej przekraczała obowiązujący czas i wynosiła 3 dni. W diagnostyce serologicznej odry ważne dla zachowania wysokiej czułości jest to, aby czas od wystąpienia wysypki do pobrania próbki krwi mieścił się w przedziale od 7 do 45 dni. Najwyższe miano obserwowane jest 8 dnia. Mediana liczby dni, które upłynęły od wystąpienia wysypki do pobrania próbki krwi wyniosła w 2016 r. 9 dni.

\section{PODSUMOWANIE I WNIOSKI}

Pomimo wzrostu liczby zachorowań na odrę w 2016 roku, w porównaniu z rokiem 2015 nadal liczba zarejestrowanych podejrzeń zachorowania na odrę pozostaje zbyt niska do oczekiwanej liczby.

W celu poprawy jakości nadzoru nad odrą w Polsce celowe jest propagowanie programu eliminacji odry wśród lekarzy i informacji na temat planu i stopnia realizacji programu oraz na temat aktualnej sytuacji epidemiologicznej choroby w Polsce. Podkreślać należy także konieczność dokumentowania i laboratoryjnego potwierdzania wszystkich przypadków zachorowań i podejrzeń zachorowań na odrę, $z$ uwzględnieniem informacji o roli laboratorium referencyjnego w realizacji programu i o możliwości wykonywania bezpłatnych badań serologicznych. 


\section{REFERENCES}

1. O'Connor, Jackovic D, Muscat M, et al. Measles and rubella elimination in the WHO Region for Europe: progress and challenges. Clin Microbiol Infect 2017 Aug;23(8):504-510.

2. World Health Organization Global measles and rubella strategic plan: 2012-2020. World Health Organization, Geneva, Switzerland (2012) [Internet] [cited 2018 Aug 29] Available from: http://apps.who. int/iris/bitstream/10665/44855/1/9789241503396_eng. pdf

3. World Health Organization Regional Office for Europe European Vaccine Action Plan 2015-2020.World Health Organization, Copenhagen (2015) [Internet] [cited 2018 Aug 29] Available from: http://www.euro.who.int/ data/assets/pdf_file/0007/255679/WHO_EVAP_UK_ v30 WEBx.pdf? ua=1

4. Baumann-Popczyk A, Sadkowska-Todys M, Zieliński A. Choroby zakaźne i pasożytnicze - epidemiologia i profilaktyka. Bielsko-Biała: a-medica press, 2014.

5. Portal Szczepienia Info, [Internet] [cited 2018 Jun 27] Available from: http://szczepienia.pzh.gov.

6. Naruszewicz-Lesiuk D. Measles in Poland in the years 1962-1968 as viewed against the background of the epidemiologic situation throughout the world. Przegl Epidemiol 1970;24(1):1-14.

7. Wang Z, Yan R, He H, et al. Difficulties in eliminating measles and controlling rubella and mumps: a crosssectional study of a first measles and rubella vaccination and a second measles, mumps, and rubella vaccination. PLoS ONE, 9 (2014).

8. Czarkowski M P, et al. Choroby zakaźne i zatrucia w Polsce w 2016 r. Warszawa: NIZP-PZH; GIS, 2017,[Internet] [cited 2018 Jun 27] Available from: http://wwwold.pzh.gov.pl/oldpage/epimeld/index_p. html\#01,

9. Czarkowski M P, et al. Szczepienia ochronne w Polsce w 2016 r. Warszawa NIZP-PZH; GIS, 2017, [Internet] [cited 2018 Jun 27] Available from: http://wwwold.pzh. gov.pl/oldpage/epimeld/index_p.html\#05,

10. Definicje przypadków chorób zakaźnych na potrzeby nadzoru epidemiologicznego, Zakład Epidemiologii NIZP-PZH, ww.pzh.gov.pl;

Received:4.09.2018

Accepted for publication: 17.09.2018

Otrzymano:4.09.2018 r.

Zaakceptowano do publikacji: 17.09.2018 r.

\section{Address for correspondence:}

Adres do korespondencji:

Iwona Paradowska-Stankiewicz

Zakład Epidemiologii Chorób Zakaźnych i Nadzoru

Narodowy Instytut Zdrowia Publicznego - Państwowy

Zakład Higieny

ul. Chocimska 24, 00-791 Warszawa

e-mail: istankiewicz@pzh.gov.pl 